\title{
IMPACT OF DIGITAL INNOVATION ON DEVELOPMENT OF AGRICULTURE IN LATVIA
}

\author{
Baiba Rivza ${ }^{1}$, Daina Vasilevska ${ }^{2}$, Peteris Rivza $^{1}$ \\ ${ }^{1}$ Latvia University of Life Sciences and Technologies, Latvia; ${ }^{2}$ Liepaja University, Latvia \\ baiba.rivza@1lu.lv, daina.vasilevska@gmail.com, peteris.rivza@1lu.lv
}

\begin{abstract}
Developed countries are successfully modernizing their economies, rapidly developing innovative technologies dominated by artificial intelligence, automation, and digital platforms. World leaders in the implementation of digital technologies are IT-companies, media, finance, and insurance. Mobile communications and the Internet have a huge impact on all sectors of the economy, and agriculture is no exception. Digital technologies increase production efficiency, complement other production factors, and stimulate innovation, significantly reduce costs, overcome information barriers that impede market access for many small farmers, expand knowledge through new ways of providing extension services and provide new ways to improve management supply chains in agriculture. The main limiting factor is the specificity of agricultural production. And although there are many examples of the positive impact of digitalization in rural areas, they often do not reach the expected level. The main reason is that technology can eliminate only some, but not all, barriers that farmers face. The aim of this research is to study the level of digitization of agriculture in Latvia, identifying the main obstacles to the introduction of digital technologies in the agricultural sector of the Latvian economy. Acceleration of digital transformations in agriculture, the formation of the digital agrarian sector of the economy depends largely on the investment climate in the country, increasing investment in the industry.
\end{abstract}

Keywords: digitalization, agriculture, rural territories, digital technologies.

\section{Introduction}

The growing population of the Earth means the increasing demand for agricultural products. By 2025, according to the United Nations projections, it will be necessary to increase food production by $70 \%$ [1]. Food demand will grow as a result of both population growth and income growth. By 2050, the demand for cereals will reach approximately 3 billion tons. Annual grain production will have to increase by almost a billion tons ( 2.1 billion tons today), and meat production by more than 200 million tons in order to reach a total of 470 million tons in 2050,72 percent (58 percent today) of which will be used in developing countries [2]. The agricultural industry can increase productivity and competitiveness, using the latest scientific advances and best practices. Developed countries are successfully modernizing their economies, rapidly developing innovative technologies, dominated by artificial intelligence, automation and digital platforms. By 2020, experts predict, $25 \%$ of the world economy will move to the introduction of digitalization technologies, allowing the state, business and society to function effectively [3].

Digitalization is an important prerequisite for helping rural regions adapt to the modern knowledge-based economy and to promote regional development and growth. Digitalization offers rural firms the opportunity to diversify into new innovative business areas and opens up local products and services for new value chains to the national and global levels.

In addition, digitalization can help reduce emigration and brain drain in urban centres and make rural areas a viable alternative for educated young people to live and work. Digital technologies offer opportunities for the development of new types of business, and this can increase the attractiveness of rural areas, especially in the eyes of the younger generation [4]. In short, the social and economic impact is very large: it affects employment and quality of life, market and value chains, competitiveness and opportunities for agricultural and rural entrepreneurs. Despite these opportunities, digitalization remains the prerogative of urban centres, and rural areas are largely ignored by policy makers and decision makers. Central to the digitalization of rural areas are no longer problems connecting to high-quality mobile and broadband services, but rather the need to promote capacity building and knowledge sharing to encourage rural firms to integrate digital models into their business plans.

According to expert estimates, during the season the farmer has to make more than 40 different decisions at limited intervals. Many of these solutions, which directly affect the economy of production, are objects of digitalization [5]. The level of digitalization of agriculture in Latvia today is 
very low: the lack of scientific and practical knowledge of innovative modern agricultural technologies and methodologies, the lack of a global forecast for agricultural prices, the lack of a sufficient number of information technology tools and equipment, as well as the underdevelopment of logistics, storage and delivery systems high production costs [6]. Only a small number of agricultural producers have the financial capacity to purchase new equipment, use of IT equipment and platforms.

The aim of the study was to study the digitalization level of agriculture in Latvia, identify the main barriers to the introduction of digital technologies in the agricultural sector of the Latvian economy.

\section{Materials and methods}

In order to conduct the study, a mixed methodology was used. The data for the study were collected from both the secondary and primary sources. For data processing and further analysis methods of data comparison, statistical grouping, analysis and synthesis were used. In the first phase, literature was obtained from the available secondary sources, journals, research papers and the reports of foreign and Latvian researchers, and institutions, as well as the data from the database of the UN, the Central Statistical Bureau of Latvia database and OECD.

At the second stage, a survey of specialists was conducted in the public and private sectors in order to collect their opinions and experience regarding the introduction of digital technologies in agricultural enterprises. The electronic survey was attended by 22 experts from the Rural Support Service, the Ministry of Agriculture, Latvian Rural Advisory and Training Centre, and the Latvian Agricultural Organization Cooperation Council.

In an interview with specialists, the following questions were answered.

1. What are the main barriers to digitalization of agriculture?

2. What are the main areas of application of digital technologies in agriculture in Latvia?

\section{Key agricultural statistics}

At the end of 2017, in Latvia there were 80.2 thousand agricultural holdings, the average size whereof constituted 36.8 ha -7.3 ha or $25 \%$ more than in 2010 . The agricultural area on average per holding increased from 19.6 ha in 2010 to 25.0 ha in 2017. Over the period, the total agricultural area in the country grew by 126.8 thousand ha or $7 \%$, reaching 1932.3 thousand ha in 2017. (Table 1)

Gross value added of agriculture, forestry and fishing at current prices in 2017 -914 million EUR. Share of agriculture, forestry and fishing in the gross value added is $3.9 \%$ [7].

Table 1

Key agricultural indicators

\begin{tabular}{|c|c|c|c|c|c|}
\hline \multicolumn{2}{|c|}{ Indicator } & 2010 & 2015 & 2016 & 2017 \\
\hline \multicolumn{2}{|c|}{$\begin{array}{l}\text { Number of agricultural holdings at the end of } \\
\text { the year, thousand }\end{array}$} & 96.4 & 83.6 & 82.4 & 80.2 \\
\hline \multirow{2}{*}{$\begin{array}{l}\text { On average per } \\
\text { holding, ha: }\end{array}$} & total land area & 29.5 & 34.8 & 35.9 & 36.8 \\
\hline & agricultural area & 19.6 & 23.6 & 24.3 & 25.0 \\
\hline \multicolumn{2}{|c|}{$\begin{array}{l}\text { Annual labour force in agriculture, forestry } \\
\text { and fishing, thousand persons }\end{array}$} & 73.3 & 71.1 & 68.7 & 61.4 \\
\hline \multicolumn{2}{|c|}{$\begin{array}{l}\text { Share of labour force in agriculture, forestry } \\
\text { and fishing, as \% of total number of employed } \\
\text { in national economy }\end{array}$} & 8.6 & 7.9 & 7.7 & 6.9 \\
\hline
\end{tabular}

Source: Central Statistical Bureau of Latvia, 2019

In 2016, there were 69.9 thousand economically active farms, which managed 1930.8 ha of utilized UAA. Compared to 2013, the total number of economically active agricultural holdings decreased by $14.5 \%$ in 2016, while the utilized agricultural area increased by $2.8 \%$.

The number of small farms decreased significantly - by $19.2 \%$ or 14.1 thousand, compared to 2013 (Table 2) [7]. 
Number of agricultural holdings (thousands)

\begin{tabular}{|c|c|c|c|c|}
\hline Holding & $\mathbf{2 0 1 3}$ & Percentage , \% & $\mathbf{2 0 1 6}$ & Percentage , \% \\
\hline All farms & 81.8 & 100 & 69.9 & 100 \\
\hline Small & 73.6 & 90.0 & 59.5 & 85.1 \\
\hline Medium & 6.8 & 8.3 & 8.4 & 12.0 \\
\hline Large & 1.4 & 1.7 & 2.0 & 2.9 \\
\hline
\end{tabular}

Source: Central Statistical Bureau of Latvia, 2019

The preservation and development of small and medium-sized farms (farms of less than 1 hectare) in rural areas is also an important issue in Latvia. The elimination of small farms will only increase the number of inhabitants, the increase in unemployment and the number of families living in deprivation in the countryside and in the country as a whole. Currently, food production and delivery to consumers is a complex system that encompasses many of the main stages: packaging, processing, transportation, wholesalers, retailers, and product advertising. The farmer, the basic stage in the food chain, is only an insignificant item for whom the smallest part of the final price of a product is paid for food.

Small farms tend to have difficulties in implementing advanced technologies, but they are not synonymous with technological backwardness. They maintain and develop, at a reasonable intensity, local natural and social resources, such as through technological and product innovation, creatively adapting various technological solutions and innovations to local conditions, enhancing and disseminating knowledge.

As Latvia is an EU Member State, in Latvia's agricultural policy Latvia relies on the EU Common Agricultural Policy supported activities, moreover, it is linked to the National Development Plan 2014-2020 and the Latvia's Rural Development Programme for 2014-2020 [8]. Future rural development in Latvia is closely related to the EU priorities for rural development:

- promoting the competitiveness of agriculture;

- ensure sustainable management of natural resources and climate action;

- achieving balanced territorial development of the rural economy and communities, for example by creating and maintaining jobs.

Digitalization is one of the most important tools, which can help solve the problem of reducing small rural enterprises and save jobs in rural areas, increase the production and marketing of food products that are produced using renewable resources.

\section{Results and discussion}

To fully exploit the potential of digital technology, you need access to the broadband Internet. National and regional authorities use the EU funding to develop high-speed broadband infrastructure and provide rural areas with the Internet. The volume of the information technology market in agriculture is developing rapidly. The state is constantly investing in ICT development in rural areas. The first round of the so-called "middle mile" broadband project completed in 2015 and cost 26 million euros. The goal of the project is to create access to the broadband service and get people fast Internet - at least 30 megabits per second [9].

Even in spite of the infrastructure provided by the state, operators are still not profitable to provide the service. The telecom company needs additional expenses to start a business to connect to the Internet. For example, you need to install devices that provide data transmission, design and coordination of the project, obtain a building permit, and ultimately build cables to each customer's home. The number of end users of the Internet is very small and it is unprofitable for business. This situation is not typical for all regions of Latvia. The most catastrophic situation is in the regions of Vidzeme and Latgale, the most sparsely populated regions, but with the largest area. In Vidzeme on the territory of $15245 \mathrm{~km}^{2}$ only 12 people live on $1 \mathrm{~km}^{2}$. In Latgale, respectively - 14550 and 18 people live on $1 \mathrm{~km}^{2}$ [7].

In order to support sustainable employment opportunities in rural areas, joint EU and national investment in infrastructure and the development of natural and human capital play an important role. 
Rural areas should have better access to public services, health care, vocational training, and new skills development programs.

Digitalization, the introduction of new technologies will not only stimulate the preservation of small farms, but also allow Latvia to make its contribution to improving the climate and the environment, including reducing $\mathrm{CO}_{2}$ emissions to the atmosphere.

According to experts, the main problems in the implementation of digitalization of agriculture are:

- Lack of funds for the introduction of ICT in most agricultural producers. As noted in this article, the so-called bipolar economy has emerged in the agrarian sector, where highly profitable farms with wide access to efficient technologies are concentrated at one pole, and farms that work on the verge of payback using obsolete technologies are at the other extreme.

- Lack of qualified personnel.

- Insufficient development of digital infrastructure in rural areas, especially in the "rural outback". Despite the fact that radical changes are taking place in this area, the digital divide between town and country remains.

Digital technologies can be the basis for developing the agricultural sector and increasing its competitiveness. The use of innovative technologies can increase agricultural production, reduce fuel consumption, improve working conditions for farmers, preserve and improve soil characteristics, significantly reducing the risk of erosion or increasing water availability.

To achieve these goals, it is necessary to develop a program for accelerated digitalization of agriculture. The program should help increase productivity and business efficiency in agriculture, provide effective financial support from the state, improve the quality of education of people in the field of IT, also influence the improvement of the living standards of the rural population.

The program should contain a plan for the phased development of digitization of agriculture. Given the specific nature of the industry, this will ensure the creation of a consistent life cycle of production and sales (Fig.1) [10].

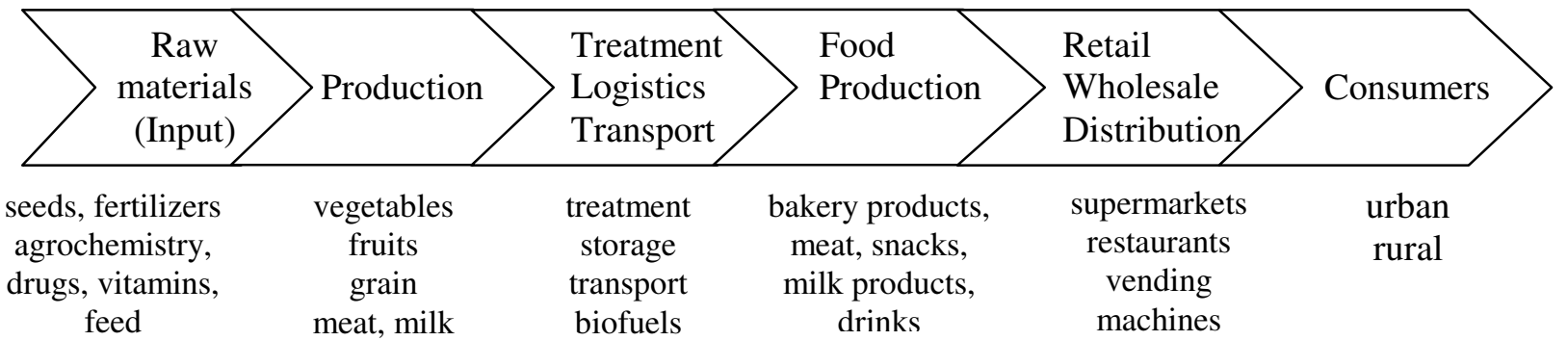

Fig. 1. Life cycle of agriculture industry

Currently, projects related to the digitalization of agriculture are being successfully implemented in Latvia. One of the most significant new concepts is known as precision farming. The purpose of precision farming is optimizing returns on inputs while preserving resources. Precision farming refers to a management concept focusing on real time observation, measurement and responses of crops, fields and animals.

In 2019, a project on the use of intelligent technologies and the use of collected data in modern dairy farming was completed [11]. The 4D4F thematic network focuses on exploring the role that dairy animal and environmental sensors can play in collecting real-time information to help make better decisions in dairy farming. The main advantages of modern technology are the following.

- Increased milk production.

- Increasing the number of calves per year.

- Extended lifespan.

- Reducing the risk of premature culling.

- Reducing labour and veterinary costs for an animal.

- More accurate heat detection and maintenance efficiency.

- The best quality of life for farmers. 
In modern farming systems there is an opportunity to improve almost all aspects of cow life, including climate control, feeding, harvesting, and milking. Touch technologies provide real-time data about each individual animal, which can help make sensible and well-informed decisions about the health status of a cow, well-being and reproductive condition.

Not all applications currently created by business developers meet the actual requirements of rural farms. The creation of the necessary technologies can be ensured only by combining the efforts of IT service providers, IT technology experts, investors and other stakeholders with farms. Only in this case applications will be created that are customized to the real needs of farmers. The state and regional authorities are crucial for promoting innovation in agriculture. They can, for example, ensure that every interested farmer can use regional infrastructure with others, for example, tested equipment, technology prototypes, the services of production laboratories.

\section{Conclusions}

In the agricultural sector today mostly older people work, and the methods of work are constantly changing. Therefore, in order to attract young people to agriculture, it is necessary to take into account their desire to use new technologies, when they are trying to develop their entrepreneurial activities; it is necessary to look for rational solutions, when they are faced with everyday needs, to share experience. Thus, investments in innovation, education and training are necessary for the future of Latvian agriculture.

For successful implementation of the program of digitalization of agriculture, the state needs to participate in the following areas:

- Development of a methodology for planning, forecasting, monitoring and reporting in the implementation of agricultural development programs;

- Creating a system of educational programs that provide retraining, formation competence frames for digital agriculture;

- Adaptation of legislation to the technological requirements necessary for the intensive introduction of digital agriculture;

- Material incentives for agricultural producers to introduce digital technologies;

- Providing support to telecommunication companies in expanding their telecommunications coverage on agricultural land;

- Maximum implementation of electronic document management, reporting; automation of public services and decision-making systems.

Digitalization is changing not only the work of agricultural enterprises, but also the entire agricultural system as a whole. The use of digital technologies can potentially, for example, improving crop yields and animals productivity, optimize the resources to be invested in the process and all this increases profitability. Digitization can also improve the working conditions of farmers and reduce the environmental impact of agriculture. This can help reduce the problems associated with isolating rural areas and increasing opportunities for social inclusion. Digital technologies offer opportunities for the development of new types of business, and this can increase the attractiveness of rural areas, especially for the younger generation.

The socioeconomic impact of digitalization is very significant: it affects employment and quality of life, the market and value chains, competitiveness and creates new development opportunities for agriculture and rural entrepreneurs.

Diversification can mean expanding the activities of rural producers in areas that are not related to agriculture. This activity is based on the natural and cultural values of the region, including farms and forests. Many approaches to the diversification of agriculture are based on the need to attract people to visit the area, so that they spend money in local stores, use local services and support local business.

\section{Acknowledgements} LV.

The preparation of the paper was supported by the National Research Program INTERFRAME - 


\section{References}

[1] United Nations report. [online] [22.02.2019]. Available at: http://www.un.org/en/development/ desa/news/population/un-report-world-population-projected-to-reach-9-6-billion-by-2050.html, 2013.

[2] Food and Agriculture Organization (FAO). [online] [30.01.2019]. Available at: http://www.fao.org/fileadmin/templates/wsfs/docx/expert_paper/How_to_Feed_the_World_in_20 50.pdf, 2009

[3] SMARTer2030 - ICT Solutions for 21st Century Challenges. Global e-Sustainability Initiative. Reviewed by Laitner, J.A., Berners-Lee, M. 2015, pp. 22-25.

[4] Rural Learning for Development: Experiences from Europe. Report on Rural Learning for Development and Book of Proceedings of the 2007 RuraLEARN Conference and Workshops. Greece, 2007, pp. 91-215, ISBN: 978-960-8339-25-1

[5] Rose D.C., Sutherland W.J., Parker C., Lobley M., Winter M., Morris C., Twining S., Foulkes CH., Amano T., Dicks L.V. Decision support tools for agriculture: Towards effective design and delivery. Agricultural Systems, volume 149, 2016, pp. 165-174.

[6] Innovation, Agricultural Productivity and Sustainability in Latvia. OECD Food and Agricultural Reviews. [online] [30.04.2019] Available at: http://www.oecd.org/latvia/innovation-agriculturalproductivity-and-sustainability-in-latvia-9789264312524-en.htm

[7] The collection of statistics "Agriculture in Latvia". Agricultural and Environment Statistics Department of CSB of Latvia, Riga, 2018, pp. 22-24.

[8] Latvia's Rural Development Program (RDP) for 2014-2020. [online] [15.01.2019] https://ec.europa.eu/agriculture/rural-development-2014-2020/country-files/lv_en

[9] VAS "Latvijas Valsts radio un televīzijas centrs. Nākamās paaudzes tīkli lauku teritorijās platjoslas projekts. [online] [10.02.2019] Available at: https://www.lvrtc.lv/platjoslasprojekts.html

[10] A Life Cycle Approach to Sustainable Agriculture Indicators. North Central Region Sustainable Agriculture Research and Education (SARE). University of Michigan, February 26-27, 1999, pp. 15-24.

[11]Data Driven Dairy Decision for Farmers (4D4F). [online] [20.02.2019].Available at: https://4d4f.eu/content/about 